\title{
Has the publishing culture in Vietnam been established yet?
}

\author{
Manh-Toan Ho
}

May 27, 2021

Six years ago, in an interview with Vietnamnet, a leading online newspaper of Vietnam, Nguyen Huu Duc of Vietnam National University at Hanoi responded that: the publishing culture has been established at VNU [1].

Albeit sounding simple and modest, the statement carried with it a not negligible weight. The statement, if true, endorsed the successful transformation to a new research-oriented education setting in the country, something unimaginable and unthinkable at the turn of the millennium [2]. But was it true?

I tend to give it some benefit of the doubt, taking into consideration assessment and reflections from other sources, such as [3-4]. Nonetheless, not once other preeminent scholars in the country had to voice their concerns over the lingering problem of misunderstanding and misperception of scientific research, investments, or efficiencies, or all together. One such heavy-weight opinion was from Vietnam, not accidentally [5].

Even if Vietnamese scholarly communities feel comfortable with the recent results, as reported by statistics from international bibliographic indexing databases, their concerns and uncertainties have not simply vanished. They will be lingering on for a (not short) while.

Let's look at how Vietnamese compare themselves to Thai counterparts in terms of scientific research [6]. Or many worry that if cash bonuses for high-quality publications are gone away, so are the publications themselves [7].

It remains to be seen if their worries will be sorted out. But it is foreseeable that actively publishing authors will soon learn that there exist limitations and weaknesses that not a single author can escape [8]. More realistic analysts would say publishing quality research will continue to be a thorny issue of the Vietnamese educational system for quite some time [9]. Therefore, low productivity and low quality in the humanities and social sciences research will continue to haunt the scholarly circle for many years to come. And the sector accepts the weaknesses at its own peril and to its own disadvantage [10]. In a larger context, the humanities and social sciences research also need to enter the psyche of Vietnamese people through effective science communication and cultural products.

Now, back to the very fundamental question posed in the title of this short discussion. Has it been established yet? 
The more realistic answer, to me, is: Highly unlikely.

\section{References}

[1] Anh, N. (2015, Jun 16). Văn hóa công bố quốc tế đã được thiết lập. Vietnamnet. https://vietnamnet.vn/vn/giao-duc/van-hoa-cong-bo-quoc-te-da-duoc-thiet-lap244237.html

[2] Vuong, Q. H. (2019). Breaking barriers in publishing demands a proactive attitude. Nature Human Behaviour, 3(10), 1034.

[3] Thuan, N. Q. (2019). Công bố quốc tế trong khoa học xã hội và nhân văn: Những vấn đề đặt ra. Tạp chí Khoa học \& Công nghệ Việt Nam. https://vjst.vn/vn/tin-tuc/1443/cong-boquoc-te-trong-khoa-hoc-xa-hoi-va-nhan-van--nhung-van-de-dat-ra.aspx

[4] Hung, T. (2020, Dec 20). Việt Nam có hơn 17.000 bài báo được công bố quốc tế năm 2020. Vietnamnet. https://vietnamnet.vn/vn/giao-duc/khoa-hoc/so-bai-bao-cong-bo-quoc-tecua-viet-nam-tang-manh-697444.html

[5] Vuong, Q. H. (2018). The (ir)rational consideration of the cost of science in transition economies. Nature Human Behaviour, 2(1), 5.

[6] Huong, P. (2017, Aug 25). Công bố quốc tế của Việt Nam chỉ bằng 1/3 Thái Lan. VNExpress. https://vnexpress.net/cong-bo-quoc-te-cua-viet-nam-chi-bang-1-3-thai-lan3632184.html

[7] Giảng, M. (2019, Dec 31). Bài báo công bố quốc tế: Khởi sắc nhờ thưởng 'khủng'. Tuổi Trẻ. https://tuoitre.vn/bai-bao-cong-bo-quoc-te-khoi-sac-nho-thuong-khung20191230204248167.htm

[8] Vuong, Q. H. (2020). Reform retractions to make them more transparent. Nature, 582(7811), 149.

[9] Yến, H. (2020, Dec 21). Công bố bài báo khoa học quốc tế: Còn lắm chông gai. Báo Đồng Nai. http://baodongnai.com.vn/tieu-diem/202012/cong-bo-bai-bao-khoa-hoc-quoc-te-conlam-chong-gai-3035661/

[10] NLD. (2019). Công bố quốc tế về xã hội - nhân văn ít ỏi là thiệt thòi của Việt Nam. Người Lao Động. https://nld.com.vn/giao-duc-khoa-hoc/cong-bo-quoc-te-ve-xa-hoi-nhan-van-it-oi-la-thiet-thoicua-viet-nam-20190117102801309.htm 